\title{
Upaya Meningkatkan Hasil Belajar Siswa Materi Huruf Hijaiyah dan Harakat Menggunakan Media Plastisin
}

\author{
Faizah $^{1}$, Siti Nur Fitriyah ${ }^{2}$ \\ ${ }^{1}$ Dosen PGMI, Institut Islam Nahdlatul Ulama Temanggung, Indonesia \\ ${ }^{2}$ Guru PAI, SDN Cengklik Surakarta, Indonesia \\ 1iezahahmad91@gmail.com
}

doi DOI: 10.37542/iq.v4i01.143

\begin{abstract}
The low results of students' scores on PAI material of hijaiyah letters theme and their harat are the main problems in this research. The reason is, students 'sociological background, students' thinking ability, less creative and innovative teachersin using learning media. This study aims to improve learning outcomes of "I Love Al-Quran_Huruf Hijaiyah and Its People" themefor grade I students of SDN Cengklik Semester 1.Using Classroom Action Research method and carried out in three cycles, namely pre-cycle, cycle I and cycle II then reflected with a comparative descriptive. Hypothesis test results obtained that the use of plasticine media can improve learning outcomes of Hijaiyah and Harakat Letters material for grade I students of SDN Cengklik Semester 1.From the initial conditions, the average achievement is 67 and the final condition is an average of 85 , which means that the student's score increases $27 \%$.
\end{abstract}

Keywords: Plasticine learning Media, Student Learning Outcomes, Hijaiyah and Harakat Letters.

\begin{abstract}
Abstrak
Rendahnya hasil nilai siswa materi PAI tema huruf hijaiyah dan harakatnya menjadi masalah pokok dalam penlitian ini. Alasannya, latar belakang sosiologi siswa, kemampuan berpikir siswa, guru kurang kreatif dan inovatif dalam menggunakan media pembelajaran. Penelitian ini bertujuan untuk meningkatkan hasil belajar tema "Aku Cinta Al-Quran_Huruf Hijaiyah dan Harakatnya" bagi siswa kelas I SDN Cengklik Semester 1. Menggunakan metode Penelitian
\end{abstract}


Tindakan Kelas dan dilakukan dalam tiga siklus yaitu pra siklus, siklus I dan siklus II kemudian direfleksi dengan diskriptif komparatif. Hasil uji hipotesis diperoleh bahwa pemanfaatan media plastisin dapat meningkatkan hasil belajar materi Huruf Hijaiyah dan Harakatnya bagi siswa kelas I SDN Cengklik Semester 1. Dari kondisi awal rata-rata prestasinya 67 dan kondisi akhir rata-ratanya 85 , yang berarti nilai siswa meningkat $27 \%$.

Kata kunci: Media pembelajaran plastisin, Hasil Belajar Siswa, Huruf Hijaiyah dan Harakat.

\section{Pendahuhuluan}

Pendidikan merupakan usaha sadar dan terencana dalam mewujudkan proses pembelajaran dan suasana belajar agar peserta didik secara aktif mengembangkan potensi diri untuk memiliki kekuatan spiritual, keagamaan, pengendalian diri, kecerdasan, kepribadian, berakhlak mulia, serta memiliki keterampilan yang diperlukan peserta didik, ketiaks bermasyarakat, bangsa dan negara. ${ }^{1}$

Pendidikan di sekolah dasar tidak hanya memberikan bekal kemampuan pengetahuan saja tetapi juga sikap dan keterampilan sebagai proses pengembangan diri dan sosial untuk melanjutkan pendidikan ke jenjang selanjutnya. ${ }^{2}$ Hal ini dikarenakan perkembangan dan perubahan di segala aspek kehidupan yang semakin pesat. Untuk itu pemerintah berupaya meningkatkan mutu pendidikan Nasional. ${ }^{3}$

Menurut Bell-Gredler belajar adalah proses yang dilakukan oleh manusia untuk mendapatkan aneka ragam kemampuan (competencies), keterampilan (skills), dan sikap (attitude) yang diperoleh secara bertahap dan berkelanjutan. Sedangkan menurut Gagne belajar merupakan sebuah sistem yang di dalamnya terdapat berbagai unsur yang saling terkait sehingga menghasilkan perilaku. ${ }^{4}$

Pengertian lain megatakan, belajar adalah proses untuk mencapai berbagai kemampuan, ketrampilan serta sikap. Mulai dari bayi hingga remaja, seseorang akan terus belajar. Ketika dewasa, diharapkan individu akan mahir dengan tugas-tugas kerja tertentu serta ketrampilan fungsional yang lain. Belajar juga merupakan aktifitas interaksi aktif individu terhadap lingkungan sehingga terjadi perubahan tingkah laku. ${ }^{5}$

\footnotetext{
${ }^{1}$ A. Akbar. Membudayakan Literasi Dengan Program 6 M Di Sekolah Dasar. JPSD. 3 (1). 42-52. 2017.

${ }^{2}$ Ngongo, dkk. Hubungan Keterlibatan Dalam Organisasi Badan (BEM) dengan Keterampilan Berpikir Kritis dan Sikap Demokratis Mahasiswa. Harmoni Sosial: Jurnal Pendidikan IPS. 4. (1). (2017). 101-112.

${ }^{3}$ Rianti, L., \& Nulhakim, L. Pengaruh Model Student Facilitator And Explaining (SFAE) Terhadap Pemahaman Konsep Siswa Kelas IV Pada Mata Pelajaran IPA. JPSD, 3 (1). (2017). 64-73.

${ }^{4}$ Karwono, \& Mularsih, H. Belajar dan Pembelajaran Serta Pemanfaatan sumber Belajar. Depok: Rajawali Pers. 2017, 13.

${ }^{5}$ Sani Abdullah Ridwan. Inovasi Pembelajaran. Jakarta: Bumi Aksara. 2014, 40.
} 
Adapun tugas guru dalam pembelajaran adalah menjadikan peserta didik belajar melalui penciptaan strategi dan lingkungan belajar yang menarik dan bermakna. Pembelajaran dapat dikatakan berhasil apabila peserta didik dapat menerima dan menguasai materi dengan baik. ${ }^{6}$

Pembelajaran Pendidikan Agama Islam (PAI) menurut Muhaimin adalah suatu upaya membuat peserta didik dapat belajar, butuh belajar, terdorong belajar, mau belajar dan tertarik untuk terus-menerus mempelajari Agama Islam, baik untuk mengetahui bagaimana cara beragama yang benar maupun mempelajari Islam sebagai pengetahuan. ${ }^{7}$

Tujuan dari pendidikan Islam menurut Syed Muhammad Naquib Al-Attas adalah menciptakan manusia beradab dalam pengertian yang menyeluruh meliputi kehidupan spiritual dan material. ${ }^{8}$ Merujuk pendapat tersebut, pembeajaran PAI memfasilitasi peserta didik untuk mengembangkan nilai-nilai spiritual yang salah satunya diaplikasikan melalui pemahaman dan penguasaan terhadap baca tulis Al-Qur'an.

Namun pada kenyataannya, kebanyakan guru sekolah dasar banyak menemui problematika terkait pemahaman dan penguasaan baca tulis Al-Qur'an siswa. Salah satunya kesulitan dalam membedakan huruf hijaiyah dan harakat. Hal tersebut tidak dapat dipungkiri, karena latar belakang sosiologi peserta didik yang multikultural.

Huruf hijaiyah merupakan huruf Arab. Huruf hijaiyah terdapat dalam Al-Qur'an dan buku yang ditulis menggunakan bahas Arab. Jumlah huruf hijayah ada 29 huruf, memiliki bentuk dan bunyi yang khusus. Cara menulis huruf hijaiyah dimulai dari arah kanan ke kiri. Huruf hijaiyah belum bisa berbunyi dan belum bisa dibaca jika belum ada tanda bacanya. Tanda baca huruf hijaiyah disebut harakat, jumlah harakat ada delapan.

Ath. Thabari, yang dikutip oleh Siswantia, menjelaskan bahwa huruf hijaiyah adalah salah satu jenis bahasa yang khas yang ditampilkan dalam al-Qur'an. Al-Qur'an memang disusun menggunakan huruf hijaiyah dengan makhraj yang berbeda sekaligus mengisyaratkan bahwa al-Qur'an diturunkan menggunakan bahasa Arab. ${ }^{9}$

6 Permatasari. Norhayati, E. Peningkatan Hasil Belajar IPA Menggunakan Model Pembelajara Kooperatif tipe TGT Berbantuan Media Gambar. JPSD. 3 (2). (2017). 96-104.

${ }^{7}$ Muhaimin, dkk. Strategi Belajar Mengajar. Surabay: Citra Media. 1996, 183.

8 Daud, Wan Mohd Nor Wan. The educational philosophy and practice of Syed Muhammad Naquib al-Attas: An exposition of the original concept of Islamization. International Inst. of Islamic Thought and Civilization, 1998.

${ }^{9}$ Siswianti, D. Meningkatkan Kemampuan Membaca Huruf Hijaiyah Melalui Metode Vakt Dengan Media Plastisin Bagi Anak Tunagrahita Ringan. Jurnal Ilmiah Pendidikan Khusus, 1 (3). (2012). 122-133. 
Problema tersebut di atas selaras dengan kondisi siswa SDN Cengklik Surakarta yang belum memahami dan menguasai huruf hijayah beserta harakatnya dengan benar. Kebanyakan siswa hafal dengan huruf hijaiyah, akan tetapi dalam menulis dan membedakan huruf hijayah tunggal dan yang berharakat masih banyak kesulitan. Selain itu masalah yang lebih urgen adalah proses pembelajaran yang kurang menyenangkan, kurang menyentuh hati, kurang memotivasi dan kurang mengesankan peserta didik, sehingga peserta didik kurang termotivasi untuk untuk memahami materi huruf hijaiyah, sehingga hasil belajarnya masih rendah.

Kondisi demikian dibuktikan dengan hasil nilai pra siklus yang didapatkan siswa kelas I SDN Cengklik Surakarta pada Semester 1 yang berjumlah 21 siswa yang beragama Islam hanya 11 siswa yang memperoleh nilai di atas Kriteria Ketutasan Minimal (KKM) atau baru $52 \%$ dari jumlah siswa yang ada dengan rata-rata kelas 67.

Berdasarkan asumsi tersebut peneliti melakukan tindakan alternatif, yaitu menggunakan media pembelajaran yang menyenangkan, bisa memotivasi peserta didik dan mengesankan, yaitu media plastisin. Dimana guru menggunakan alat bantu/media plastisin untuk menerangkan materi dan memfasilitasi siswa untuk aktif belajar. Plastisin adalah adonan lunak dengan berbagai warna yang dapat dibuat menjadi bentuk yang lain. Bermain plastisin memberikan kesenangan dan kepuasan pada anak-anak. ${ }^{10}$

Dengan media plastisin yang berwarna warni dan sudah dibentuk huruf-huruf hijayah dan harakat, guru mengenalkan huruf dengan cara diangkat, dibolak balik sambil diucapkan hurufnya dengan benar sehingga anak langsung bisa melihat huruf dan mendengar secara jelas.

Selanjutnya anak juga diberi plastisin yang masih utuh belum berbentuk huruf hijaiyah supaya dibuat huruf secara kelompok-kelompok, dengan kemampuan heterogen, jenis kelamin berbeda, saling membantu, dan memberikan kesempatan kepada semua siswa untuk dapat terlibat secara aktif dalam proses berpikir dalam kegiatan pembelajaran.

Alasan memilih plastisin selain murah, mudah didapat dan aman, plastisin sangat efektif digunakan sebagai media pembelajaran anak-anak dalam memahami berbagai bentuk termasuk bentuk huruf hijaiyah dan harakat, anak dengan mudah memahami bentuk huruf hijayah dan harakat karena anak akan langsung praktik mengenal dan membentuk huruf dengan rasa senang, kreatif dan tidak bosan.

Selain itu Jatmika, yang dikutip Arlinah, menyatakan bahwa plastisin memiliki banyak manfaat bagi anak, diantaranya adalah: 1) Melatih kemampuan sensorik, alah satu cara anak

${ }^{10}$ Reni Puspita Sari, Een Yayah Haenilah, and Ari Sofia. "Pengaruh penggunaan bermain plastisin terhadap peningkatan kreativitas anak usia 5-6 Tahun." Jurnal Pendidikan Anak Vol.1 No.3 (2015). 
mengenal sesuatu adalah melalui sentuhan, dengan bermain plastisin anak belajar tentang tekstur dan cara menciptakan sesuatu. 2) Mengembangkan kemampuan berfikir, bermain plastisin bisa mengasah kemampuan berfikir anak. 3) Berguna meningkatkan Self esteem. Bermain plastisin merupakan bermain tanpa aturan sehingga berguna untuk mengembangkan imajinasi dan kreativitas anak, sekaligus mengajarkan tentang pemecahan masalah. 4) Mengasah kemampuan berbahasa. Meremas, berguling, dan memutar adalah beberapa kata yang sering didengar anak saat bermain plastisin. 5) Memupuk kemampuan sosial. Hal ini karena dengan bermain bersama memberi kesempatan berinteraksi yang akrab, dan bisa belajar bahwa bermain bersama sangat menyenangkan. ${ }^{11}$

\section{Metode Penelitian}

Penelitian ini merupakan Penelitian Tindakan Kelas (PTK) sebagai upaya investigasi terkendali yang berdaur ulang dan bersifat reflektif mandiri, yang memiliki tujuan untuk melakukan perbaikan-perbaikan terhadap sistem, cara kerja, proses, isi, kompetensi, atau situasi. ${ }^{12}$ Yang menggunakan beberapa tipe tekhnik metode pengumpulan data, yaitu observasi, dokumentasi, wawancara kemudian hasil akhir berupa tes soal.

Subjek penelitian ini adalah siswa kelas I A SDN Cengklik Surakarta pada semester 1, secara keseluruhan sebanyak 25 siswa terdiri dari laki-laki 11 siswa dan perempuan sebanyak 14 siswa, akan tetapi yang diteliti hanya siswa yang beragama Islam saja yang berjumlah 21 siswa terdiri dari 9 siswa laki-laki dan 12 siswa perempuan.

Data dianalisis dengan menggunakan teknik diskriptif komparatif dilanjutkan dengan analisis kritis melalui refleksi. Adapun rincian tahapan-tahapan tindakan seperti gambar di bawah ini:

\section{Gambar 1.}

Siklus dalam PTK

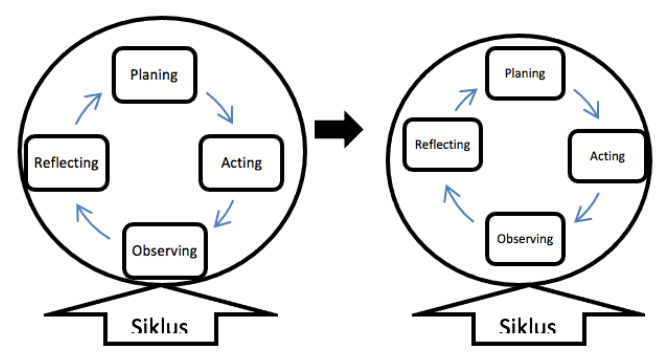

${ }^{11}$ Arlinah, S. \& Rohita. Meningkatkan Kreativitas Anak Melalui Bermain Plastisin Pada Kelompok A Di Paud Plus Al Fattah Jarak Kulon Kabupaten Jombang. Paud Teratai: Jurnaal Ilmiah Pendidikan Anak Usia Dini. 3 (3). 2014, 3.

${ }^{12}$ Basuki Wibawa. "Penelitian Tindakan Kelas." Jakarta: Dirjen Dikdasmen (2003): 2721-2572. 
Faizah, Siti Nur Fitriyah

\section{Hasil Dan Pembahasan}

Berdasarkan data hasil nilai pra siklus didapatkan data siswa yang memperoleh nilai diatas KKM hanya 11 anak dari siswa 21 yang beragama Islam, sedangkan sisanya 10 anak hasil nilainya masih di bawah KKM atau baru mencapai $52 \%$ dan anak yang sudah tuntas dengan nilai rata-rata kelas 67.

Berikut tabel perolehan nilai siswa:

Tabel 1.

Hasil belajar kondisi awal

\begin{tabular}{|c|l|c|}
\hline No & \multicolumn{1}{|c|}{ Uraian } & Prestasi \\
\hline 1 & Nilai terendah & 21 \\
\hline 2 & Nilai tertinggi & 90 \\
\hline 3 & Nilai rata-rata & 67 \\
\hline 4 & Rentang nilai & 69 \\
\hline
\end{tabular}

Gambar 2.

Diagram hasil belajar kondisi awal

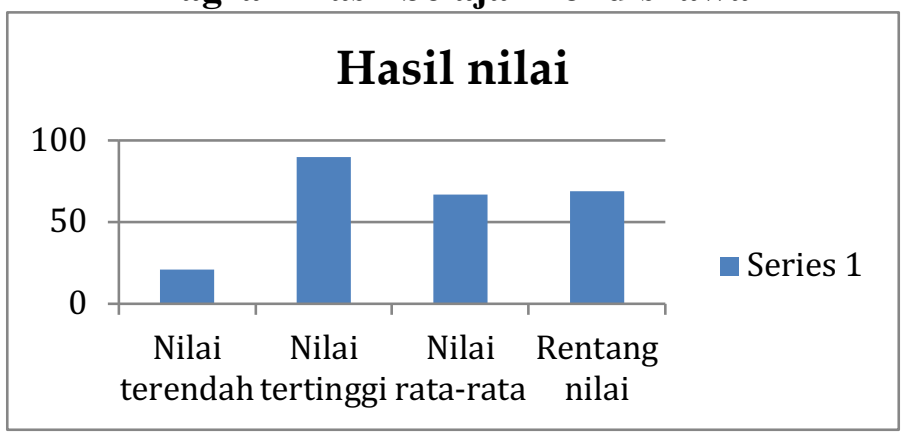

Tabel 2.

Ketuntasan hasil belajar kondisi awal

\begin{tabular}{|c|c|c|}
\hline No & Tuntas & Tidak Tuntas \\
\hline 1 & 11 anak & 10 anak \\
\hline
\end{tabular}

Gambar 3.

Diagram ketuntasan hasil belajar kondisi awal

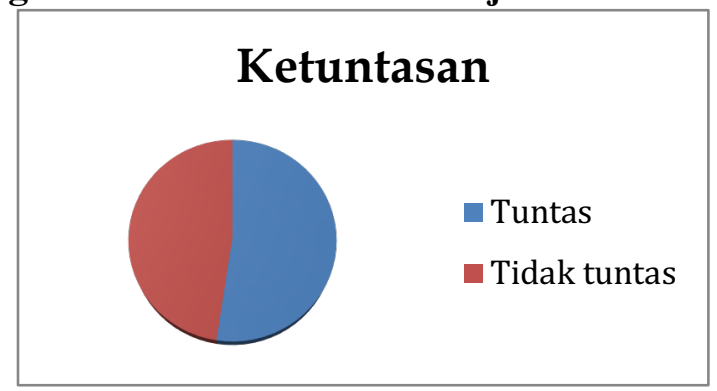


Berdasarkan pengamatan yang dilakukan, ditemukan beberapa permasalahan, yaitu: 1) Metode pembelajaran belum variatif, 2) Media yang digunakan belum menarik. 3) Tidak adanya umpan balik yang dilakukan. 4) Penguasaan pemahaman siswa pada materi masih rendah. 5) Beberapa siswa masih belum fokus dalam pembelajaran terlihat berbincang-bincang dengan temannya. 6) Siswa tidak berani mengajukan pertanyaan. 7) Siswa belum sepenuhnya termotivasi dan konsisten untuk mengikuti kegiatan pembelajaran.

Setelah dilakukan evaluasi, ternyata pemilihan media yang kurang tepat menjadi faktor utama penyebabnya. Guru hanya menggunakan media bergambar dari kertas. Hal ini menyebabkan peserta didik merasa jenuh dan kurang termotivasi untuk mengikuti proses pembelajaran.

Setelah hasil belajar peserta didik rendah pada tahap Prasiklus, maka penulis melanjutkan melakukan Perbaikan Pembelajaran pada Siklus I. Pada siklus ini, digunakan metode bernyanyi dan media plastisin.

Sesuai dengan metode dan media yang digunakan, berikut tahap awal persiapan, 1) Guru menyusun rencana pembelajaran tema Aku Cinta Al-Qur`an dan subtema huruf hijaiyah dan harakat. 2) Menyusun metode, media dan strategi pembelajaran. 3) Meyiapkan sumber belajar dan materi. 4) Menyusun alat evaluasi pembelajaran berupa tes soal.

Tahap pendahuluan dengan waktu 10 menit guru melakukan; 1) Mengucapkan salam dan berdo'a bersama dipimpin oleh salah satu siswa dengan penuh khidmat. 2) Bersama-sama membaca Al-Qur'an surat Alfatihah. 3) mengisi lembar kehadiran dan memeriksa kerapihan pakaian, posisi dan tempat duduk siswa. 4) Memberikan motivasi belajar kepada siswa melalui "tepuk alfatihah" sembari review materi lalu dan bernyanyi huruf hijaiyah menggunakan nada upin ipin. 5) Menyampaikan kompetensi dasar dan tujuan pembelajaran.

Kegiatan inti dengan waktu 50 menit melakukan; 1) Tanya jawab dan review materi sebelumnya. 2) Menyampaikan materi dan melafalkan huruf hiyaiyah tunggal (tanpa harakat) kepada siswa. 3) Siswa mengidentifikasi dan memetakan huruf-huruf yang dianggap sulit ditulis maupun dibaca. 5) Siswa membentuk kelompok, ketua kelompok mengambil kertas yang berisi penjelasan materi. 6) Ketua kelompok menjelaskan materi yang sudah disampaikan kepada temannya. 7) Tiap kelompok diberikan plastisin dan dibentuk huruf hijaiyah tunggal sesuai perintah yang ada di kertas. 8) tiap kelompok bekerja sama membuat huruf hijaiyah dan meletakkan ke tempat yang sudah disediakan. 9) tiap kelompok mempresentasikan (melafalkan huruf hijaiyah), kelompok lain mengikuti. 10) Permainan berlangsung berkali-kali pada tiap kelompok hingga siswa menguasai pelafalan huruf hijaiyah secara keseluruhan. 
Pelaksanaan kegiatan penutup kurang lebih 10 menit, antara lain; 1) Penilaian dan refleksi dengan mengajukan pertanyaan/ tanggapan peserta didik dari kegiatan yang telah dilaksanakan sebagai bahan masukan untuk perbaikan langkah selanjutnya. 2) Mengisi lembar evaluasi lalu dikumpulkan. 3) Siswa diberi kesempatan untuk bertanya materi yang belum jelas (keberanian). 4) Menyimpulkan materi bersama-sama kemudian pemberian motivasi. 5) Pemberian tugas dan penyampaian materi selanjutnya. 6) menutup pembelajaran dengan mengucap salam dan do'a.

Berdasarkan hasil pembelajaran siklus I menggunakan media plastisin hasil nilai terendah adalah 52, nilai tertinggi 97, nilai rata-rata 82 dengan rentang nilai 45. Jika dilihat dari sisi ketuntasan anak, yang mendapat nilai di bawah KKM menurun menjadi 3 anak dan di atas KKM meningkat menjadi 18 anak. Berikut uraian data siklus I:

Tabel 3.

Hasil belajar Silkus I

\begin{tabular}{|c|l|c|}
\hline & \multicolumn{1}{|c|}{ Uraian } & Prestasi \\
\hline 1 & Nilai terendah & 52 \\
\hline 2 & Nilai tertinggi & 97 \\
\hline 3 & Nilai rata-rata & 82 \\
\hline 4 & Rentang nilai & 45 \\
\hline
\end{tabular}

Gambar 4.

Diagram batang hasil belajar siklus I

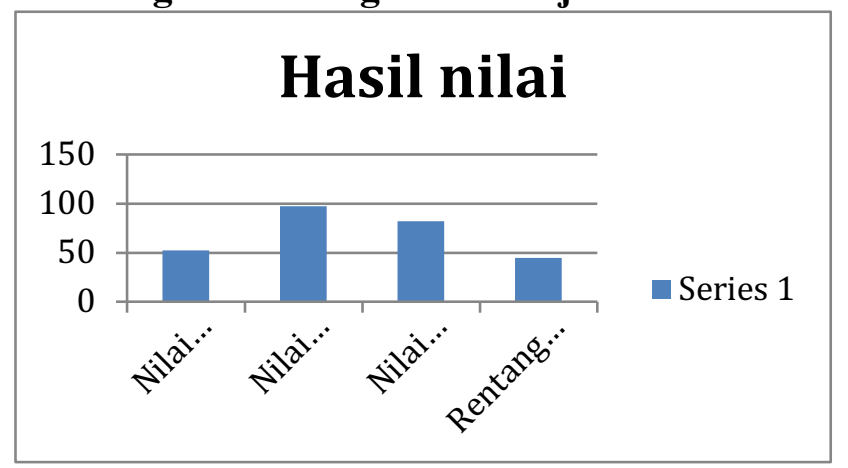

Tabel 4.

Ketuntasan hasil belajar siklus I

\begin{tabular}{|c|c|c|}
\hline No & Tuntas & Tidak Tuntas \\
\hline 1 & 18 anak & 3 anak \\
\hline
\end{tabular}


Gambar 5.

\section{Diagram ketuntasan hasil belajar siklus I}

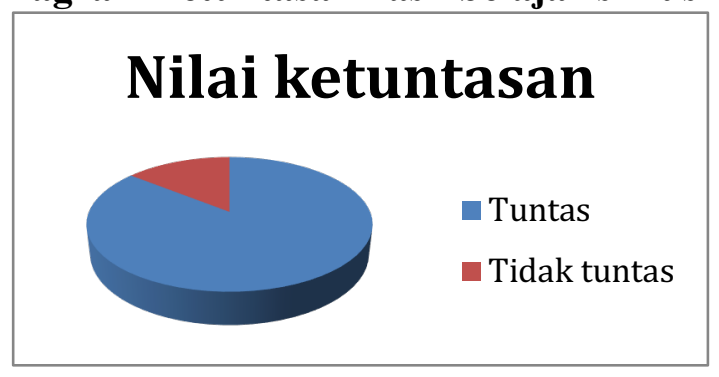

Kesimpulannya, penggunaan media plastisin pada siklus I masih didapatkan beberapa permasalahan, antara lain; 1) Masih ada 3 anak yang belum tuntas pembelajaran. 2) Tidak semua siswa langsung memahami penggunaan media plastisin. 3) keterlibatan siswa dalam pembelajaran masih kurang, ada beberapa siswa yang sibuk sendiri.

Namun jika dilihat dari nilai akhir siswa, terdapat beberapa perkembangan dan kenaikan dari pemerolehan nilai pada pra siklus, pemahaman materi tergolong naik. Kondisi pembelajaran juga lebih tenang, tidak gaduh dan lebih efektif. Kebanyakan siswa juga langsung antusias dan semangat menggunakan media plastisin.

Selanjutnya dilakukan perbaikan pembelajaran pada siklus II, pada siklus ini pembelajaran menggunakan media plastisin yang dikembangkan lebih menarik lagi.

Tahap awal yaitu persiapan yang hampir sama pada siklus I, yaitu 1) Menyusun rencana pembelajaran. 2) Menyusun metode dan media pembelajaran berupa ceramah, tanya jawab, diskusi dan media plastisin. 3) Persiapan sumber belajar. 4) Penyusunan alat evaluasi berupa soal-soal.

Pada tahap pelaksanaan yang terdiri dari kegiatan awal dengan waktu 10 menit dengan pelaksanaan yang hampir sama dengan siklus I.

Pelaksanaan kegiatan inti dengan waktu \pm 50 menit, antara lain 1) Guru menyampaikan materi dan melafalkan hruf hijaiyah berharakat, siswa menirukan. 2) Siswa mengidentifikasi huruf yang sulit ditulis maupun dibaca, kemudian dipetakan. 3) Membentuk kelompok siswa seperti pertemuan yang lalu, ketua kelompok menjelaskan materi kepada temannya. 4) Tiap kelompok diberikan plastisin untuk dibentuk harakat sesuai perintah yang ada di kertas. 5) Tiap kelompok bekerja sama membuat harakat dan meletakkan ke tempat yang sudah disediakan. 6) Siswa berkreasi menyusun kata-kata dengan huruf hijaiyah dan harakat dari huruf yang didapakan tiap kelompok. 7) Siswa mempresentasikan tugas, melafalkan kata-kata hijaiyah. 8) Permainan ini berlangsung berkali-kali pada tiap-tiap kelompok hingga siswa menguasai pelafalan huruf hijaiyah berharakat secara mendalam. 
Kegiatan Penutup dengan waktu 10 menit melakukan 1) siswa mengisi lembar evaluasi secara individu lalu dikumpulkan. 2) siswa diberi kesempatan untuk bertanya hal-hal yang belum jelas (keberanian). 3) Siswa bersama guru menyimpulkan materi pelajaran. 4) Penilaian hasil evaluasi. 5) Pemberian umpan balik. 6) Guru menutup pelajaran dengan mengucapkan salam dan doa dipimpin siswa.

Hasil pengamatan didapatkan bahwa terdapat perubahan cukup berbeda dan peningkatan yang cukup pesat pada siklus II. Mulai dari meningkatnya nilai belajar siswa, motivasi siswa tinggi, pembelajaran yang semakin kondusif, siswa semakin aktif bertanya ataupun menjawab pertanyaan bahkan sebagian siswa sudah mampu mengkritisi di luar materi pembelajaran.

Berikut uraian hasil belajar siklus II, nilai terendah adalah 62, nilai tertinggi 100, nilai rata-rata 85 dengan rentang nilai 38. Jika dilihat dari sisi ketuntasan anak, yang mendapat nilai di bawah KKM tetap 3 anak dan yang di atas KKM juga tetap 18 anak. Akan tetapi dari 3 anak yang mendapat nilai di bawah KKM tersebut semuanya menunjukkan adanya peningkatan hasil belajar dari siklus sebelumnya. Berikut datanya:

Tabel 5.

Hasil belajar Silkus II

\begin{tabular}{|c|l|c|}
\hline & \multicolumn{1}{|c|}{ Uraian } & Prestasi \\
\hline 1 & Nilai terendah & 62 \\
\hline 2 & Nilai tertinggi & 100 \\
\hline 3 & Nilai rata-rata & 85 \\
\hline 4 & Rentang nilai & 38 \\
\hline
\end{tabular}

Gambar 6.

Diagram batang hasil nilai siklus II

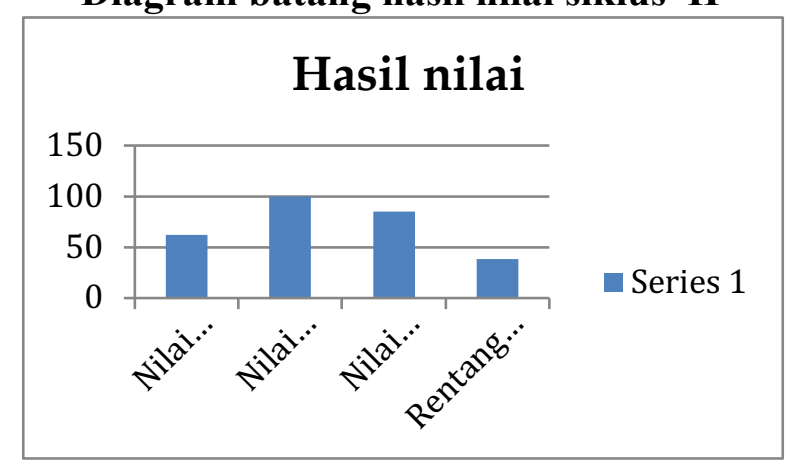

Tabel 6.

Hasil belajar Silkus II

\begin{tabular}{|c|c|c|}
\hline No & Tuntas & Tidak Tuntas \\
\hline 1 & 18 anak & 3 anak \\
\hline
\end{tabular}


Gambar 7.

Diagram ketuntasan hasil belajar siklus II

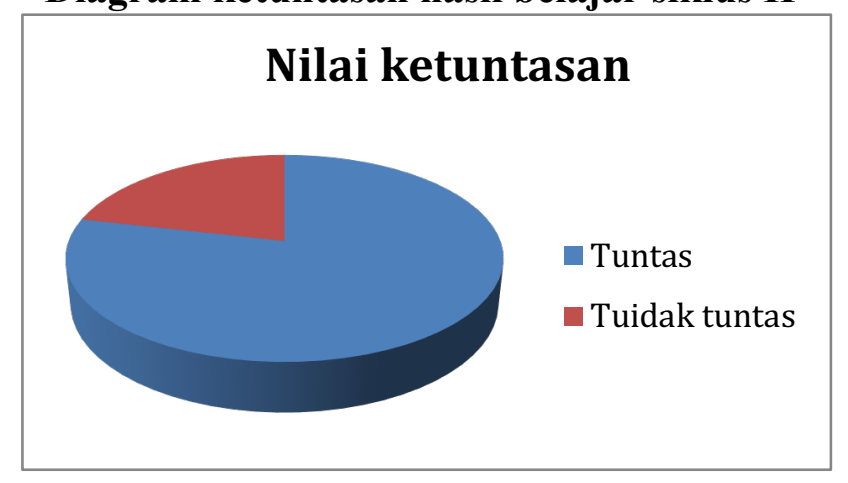

Dari pengamatan yang dilakukan mulai dari pra siklus hingga siklus II dapat disimpulkan bahwa penggunaan media plastisin sangat efektif dan berpengaruh pada hasil belajar materi huruf hijaiyah dan harakatnya. Hal ini dapat membantu kesulitan yang dialami siswa dalam memahami dan menulis huruf hijaiyah, karena cukup menyenangkan dan tidak membosankan.

Lebih lanjut, media merupakan sarana penyalur pesan atau informasi belajar yang hendak disampaikan oleh sumber pesan kepada sasaran atau penerima pesan tersebut. Penggunaan media pengajaran dapat membantu pencapaian keberhasilan belajar. Ditegaskan oleh Danim bahwa hasil penelitian telah banyak membuktikan efektivitas penggunaan alat bantu atau media dalam proses belajar-mengajar di kelas, terutama dalam hal peningkatan prestasi siswa. Terbatasnya media yang dipergunakan dalam kelas diduga merupakan salah satu penyebab lemahnya mutu belajar siswa. ${ }^{13}$

Selain itu, media plastisin juga sangat mudah didapatkan karena harganya yang cukup ramah dikantong namun dapat dimanfaatkan sangat kreatif. Seperti pendapat Winkel yang dikutip Mahnun, bahwa pemilihan media disamping melihat kesesuiannya dengan tujuan intruksional khusus, materi pelajaran, prosedur didaktis dan bentuk pengelompokan siswa, juga harus dipertimbangkan soal biaya (cost factor), ketersediaan peralatan waktu dibutuhkan (avaibility factor), ketersediaan aliran listrik, kualitas teknis (technical cuality), ruang kelas, dan kemampuan guru menggunakan media secara tepat (technical know-how). ${ }^{14}$

13 S. Danim. Media Komunikasi Pendidikan. Jakarta: Bumi Aksara. 1995, 1.

14 Nunu Mahnun. "Media pembelajaran (kajian terhadap langkah-langkah pemilihan media dan implementasinya dalam pembelajaran)." An-Nida' Vol. 37 No. 1 (2012): 27-34. 
Faizah, Siti Nur Fitriyah

\section{Kesimpulan}

Pemanfaatan media plastisin dapat meningkatkan hasil belajar materi Huruf Hijaiyah dan Harakatnya siswa kelas I SDN Cengklik Semester 1. Dari kondisi awal rata-rata prestasi siswa 67 naik menjadi rata-rata 85, yaitu meningkat $27 \%$. Dari kesimpulan di atas ada beberapa hal yang seharusya dilakukan oleh guru dalam upaya meningkatkan hasil belajar khususnya pada mata pelajaran PAI materi huruf hijaiyah dan harakat sebagai upaya meningkatkan keaktifan siswa saat proses pembelajaran. Antara lain; 1) refleksi diri dan perbaikan terus menerus dilakukan dalam proses belajar mengajar. 2) Adanya inovasi pembelajaran khususnya kreativitas dalam penggunaan metode dan media pembelajaran. 3) Hendaknya melakukan PTK untuk memperbaiki pembelajaran. 4) Penggunaan media plastisin dapat diterapkan sebagai upaya mengganti media-media yang mahal. 6) Guru hendaknya sering membaca referensi baru, mengikuti pelatihan dan seminar-seminar Nasional maupun International sebagai upaya upgrade profesionalitas dan kualitas.

\section{Daftar Pustaka}

Akbar, A. Membudayakan Literasi Dengan Program 6 M Di Sekolah Dasar. JPSD. 3 (1). 42 52. 2017.

Arlinah, S. \& Rohita. Meningkatkan Kreativitas Anak Melalui Bermain Plastisin Pada Kelompok A Di Paud Plus Al Fattah Jarak Kulon Kabupaten Jombang. Paud Teratai: Jurnaal Ilmiah Pendidikan Anak Usia Dini. 3 (3). 2014.

Danim, S. Media Komunikasi Pendidikan. Jakarta: Bumi Aksara. 1995.

Daud, Wan Mohd Nor Wan. The educational philosophy and practice of Syed Muhammad Naquib al-Attas: An exposition of the original concept of Islamization. International Inst. of Islamic Thought and Civilization, 1998.

Dynna, W. P. S. Departemen Psikologi Pendidikan dan Perkembangan Fakultas Psikologi Universitas Airlangga. Jurnal Psikologi Pendidikan dan Perkembangan. 2 (03). (2013). $1-5$.

Karwono, \& Mularsih, H. Belajar dan Pembelajaran Serta Pemanfaatan sumber Belajar. Depok: Rajawali Pers. 2017.

Mahnun, N. Media pembelajaran (kajian terhadap langkah-langkah pemilihan media dan implementasinya dalam pembelajaran). Jurnal Pemikiran Islam. 37 (1). (2012). 27-34.

Mahnun, Nunu. "Media pembelajaran (kajian terhadap langkah-langkah pemilihan media dan implementasinya dalam pembelajaran)." An-Nida' Vol. 37 No. 1 (2012): 27-34.

Muhaimin, dkk. Strategi Belajar Mengajar. Surabay: Citra Media. 1996.

98 | IQ (Ilmu Al-qur'an): Jurnal Pendidikan Islam | Volume 4 No.01 2021, 87-100 

dan Harakat Menggunakan Media Plastisin

Ngongo, dkk. Hubungan Keterlibatan Dalam Organisasi Badan (BEM) dengan Keterampilan Berpikir Kritis dan Sikap Demokratis Mahasiswa. Harmoni Sosial: Jurnal Pendidikan IPS. 4. (1). (2017). 101-112.

Permatasari. Norhayati, E. Peningkatan Hasil Belajar IPA Menggunakan Model Pembelajara Kooperatif tipe TGT Berbantuan Media Gambar. JPSD. 3 (2). (2017). 96-104.

Rianti, L., \& Nulhakim, L. Pengaruh Model Student Facilitator And Explaining (SFAE) Terhadap Pemahaman Konsep Siswa Kelas IV Pada Mata Pelajaran IPA. JPSD, 3 (1). (2017). 64-73.

Sani Abdullah Ridwan. Inovasi Pembelajaran. Jakarta: Bumi Aksara. 2014.

Sari, Reni Puspita, Een Yayah Haenilah, and Ari Sofia. "Pengaruh penggunaan bermain plastisin terhadap peningkatan kreativitas anak usia 5-6 Tahun." Jurnal Pendidikan Anak Vol. 1 No. 3 (2015).

Siswianti, D. Meningkatkan Kemampuan Membaca Huruf Hijaiyah Melalui Metode Vakt Dengan Media Plastisin Bagi Anak Tunagrahita Ringan. Jurnal Ilmiah Pendidikan Khusus, 1 (3). (2012). 122-133.

Wibawa, Basuki. "Penelitian Tindakan Kelas." Jakarta: Dirjen Dikdasmen (2003): 2721-2572. 
Faizah, Siti Nur Fitriyah

100 | IQ (Ilmu Al-qur'an): Jurnal Pendidikan Islam| Volume 4 No.01 2021, 87-100 